University of Wollongong

Research Online

Faculty of Social Sciences - Papers (Archive) Faculty of Arts, Social Sciences \& Humanities

1989

Bioethics, Faith and Reason: Recent Writing in Medical Bioethics

Neville Hicks

University of Adelaide

Annette J. Braunack-Mayer

University of Wollongong, abmayer@uow.edu.au

Follow this and additional works at: https://ro.uow.edu.au/sspapers

Part of the Education Commons, and the Social and Behavioral Sciences Commons

Research Online is the open access institutional repository for the University of Wollongong. For further information contact the UOW Library: research-pubs@uow.edu.au 


\title{
Bioethics, Faith and Reason: Recent Writing in Medical Bioethics
}

\author{
Abstract \\ Reviews five medical bioethics texts \\ Keywords \\ writing, medical, recent, reason:, faith, bioethics, bioethics \\ Disciplines \\ Education | Social and Behavioral Sciences \\ Publication Details \\ Hicks, N. \& Braunack-Mayer, A. (1989). Bioethics, Faith and Reason: Recent Writing in Medical Bioethics. \\ Community Health Studies, 13 (2), 229-235.
}




\section{REVIEW ARTICLE}

\section{Bioethics, Faith and Reason: Recent Writing in Medical Bioethics*}

Neville Hicks and Annette Braunack-Mayer

Department of Community Medicine. The University of Adelaide.

At least three of these books are taith statements. One is a summa or an apologia (the distinction is rarely clear) and one is a sequel to an earlier summa. They are worth considering from that perspective at a time when medical ethics is being treated in Australia as yet another value-neutral technology: "All medical students should do communications skills, so they can manage the difficult patient better. Oh, yes - and ethics, too".

It is usually thought poor form to refer to a writer personally, before considering his book. There is a temptation to transgress the rule in the case of Tristram Engelhardt because he has been one of the more noticeable performers at major ethics conferences in Australia in 1986 and 1987. On each occasion he has played the role of the Texas libertarian - a state (in both senses) where cowboy boots add a macho inch, where a man must do what a man must do and where he may need a gun to do it. Engelhardt has also displayed impressive erudition in three or four languages and two disciplines - he carries a scholar's six-gun.

It is Engelhardt's opinion, shared with MacIntyre, that the Western religious consensus evaporated after Luther and the Western hope of a rationalist and universal morality evaporated after the Enlightenment.' Hence the current problem is "how to fashion an ethic for biomedical problems that can speak with rational authority across the great diversity of moral viewpoints". Engelhardt thinks that codes of law and religious traditions are "too parochial or too arbitrary to bind together individuals from varying traditions or communities". It follows that we need a secular bioethics but he can find no basis for secular ethics that does not lead to the brink of relativism. Faced with that difficulty, he argues that "ethics is an enterprise in controversy resolution". If it achieved no more than that, ethics would be a socially valuable enterprise but, in travelling to that point, Engelhardt has already left behind the 'Foundations' in his title. ${ }^{2}$

Relativism is a nuisance but distinct moral values, nurtured in communities, remain important because we learn through them what is good, worthwhile and right (or not) to do. ${ }^{3}$ There is a problem, however: the people who are trying to resolve controversy by 'doing ethics' are schooled in discrete moral values, nurtured in communities, and the principles that they can agree on will be low in content, while principles that are high in content will be difficult to generalize. This observation is the foundation of Engelhardt's general argument that ethics is a contention between two principles, autonomy and beneficence. Autonomy has universal application but minimal informative content: beneficence can have substantial specific content but is culture-specific:

"At the very roots of ethics there is a tension . . . between respecting the freedom and securing the best interests of persons".

Much of The Foundations of Bioethics represents an attempt to work through the consequences of that tension. In addition, Engelhardt finds himself obliged to discuss what is meant by "persons". He makes the Kantian assumption that moral concern is focussed on persons, not just humans. A person in the strict sense

*Christie RJ and Hoffmaster CB. Ethical issues in family medicine. New York: Oxford University Press, 1986.

Daniels N. Just Health Care. New York: Cambridge University Press, 1985.

Engelhardt HT. The Foundations of Bioethics. New York: Oxford University Press, 1986.

Shelp EE. Born to die? Deciding the fate of critically ill newborns. New York: The Free Press, 1986.

Veatch RM. The foundations of justice: Why the retarded and the rest of us have claims to equality. New York: Oxford University Press, 1986. 
is a moral agent, he says, to be distinguished from a person in the social sense, who is accorded rights without duties in a socially variable fashion. Moral persons must be self-conscious, free to choose, rational, and able to understand the pertinence of blame and praise. (People who care for the advanced aged might begin to worry, at this point, how many of their charges would pass the personhood test and what is to be done to or for them if they do not pass.)

Engelhardt claims that the intention of his distinction between persons in the strict and social senses is to make it impossible to duck the moral standard of persons in the strict sense. He defends the social assignment of social personhood on the grounds that "utilitarianism has been responsible for a great proportion of the liberal advances" in the rights of the retarded and the senile. That looks a particularly slippery defence: it depends not on philosophical arguments but on historical ones which many social historians would regard as unsettled. In addition, it is utilitarianism, whether claiming the label or not, which drives much present effort to retrench the rights of the retarded and the senile. To reduce the matter to a phrase, there is a high probability that Kantianism forced to marry utilitarianism will change its name to utilitarianism.

The suspicion that what Engelhardt is defending is a Texas-libertarian-Kantian person deepens when he argues that human foetal and embryonic life have only the value that they have for actual (that is, social) persons. Actual persons contemplating the termination of a pregnancy may be social persons with mortgages and prospective careers; actual persons contemplating what might be needed to sustain decent care for the demented elderly are social persons who vote on taxes. Their taxes are paid to governments to which Engelhardt will allow only that authority which does not interfere with the "consensual action of free individuals, including the use of their private property".

In his chapters on "The Languages of Medicalization" and on "Free and Informed Consent". Engelhardt does recognize the kinds of powers in society which make it difficult to settle for an ethic which concentrates on persons in the strict sense. Practitioners, who are active daily in health care, develop authority relative to patients, who are intermittent visitors to that arena. Professions with authority are likely to acquire political power that other people cannot command. Power and authority always threaten to push beneficence into the ditch of paternalism, where it will drown autonomy. Engelhardt recognizes these problems but his faith in the liberty of individuals makes it difficult for him to contemplate, say, the doctrines of justice which attract other ethicists.
Consider, for example, the story of Eddie Conrad, a mentally retarded 10-year-old with hearing, visual and speech impairments. Eddie's school is unable to afford the intensive speech therapy he needs without cutting other services, like the art, music and physical education curricula. How are the parents, teachers and school to reconcile Eddie's claims for fair treatment with those of the rest of the school community? Veatch begins The Foundations of Justice with this vignette and weaves it into his analysis of how to distribute health care resources justly.

The Foundations of Justice builds on the thesis Veatch developed in $A$ Theory of Medical Ethics. ${ }^{4}$ In the Theory. . ., he argued that rational people would agree on a contract for their society which incorporated a number of basic ethical principles. Different philosophical assumptions and premises might motivate different people, so the contract would have three tiers: a broad, Rawlsian social contract on which all would agree; a second contract between society and the professions it licenses; and particular contracts - for example, between mothers and home-birthing doctors. One of the problems which the three-tiered approach acknowledged was that consensus seems to disintegrate when questions of justice and the allocation of resources are raised: religious thinkers, for example, tend to opt for an egalitarian notion of justice; secular thinkers hold a diversity of views. In Engelhardt's terms, justice is rich in content but parochial in acceptability.

In The Foundations of Justice Veatch sets himself the ambitious task of formulating a principle of justice acceptable to all people. He begins with a historical survey of the notion of equality in Jewish and Christian thought, showing that both religions have maintained a stream of concern for the poor, the weak and the oppressed. The theological justification for this concern lies in their shared doctrines of God (before whom all people are equal in their finitude), Creation (all resources are a gift from God) and Stewardship (finite people have their resources on trust). From these doctrines it is only a short step to an egalitarian principle of justice which distributes resources between creatures (usually only human ones, in practice!) on the basis of need.

Secular philosophers struggling with the principle of justice appeal not to faith but to reason and experience. Veatch considers the premises and arguments of these secular perspectives under three headings - Rawlsian egalitarianism, utilitarianism and Nozick's entitlement position (which Engelhardt probably would find most congenial) and finds that the logic and rationality dance upon an underlying set of unargued (and unarguable) assumptions about the nature of humanity, 
ownership of property and human responsibility for others. Veatch's assessment is that whether one adopts an egalitarian or anti-egalitarian stance will depend ultimately on "faith moves" that are similar to those made within the Jewish or Christian tradition.

Despite having argued that there is no logical priority of one set of beliefs over others, Veatch concludes that egalitarianism is the more "natural" and more "plausible" option. The rest of the book articulates a theory of justice which is radically egalitarian and demands striving for equality of outcome. His equality of outcome is really a very 'strong' version of equality of opportunity: it would discriminate in favour of the person born with only four fingers to ensure to that person the same opportunity of winning the Chopin prize as someone with ten fingers. In practice, Veatch believes that this radical egalitarianism will mean directing far more resources into medical and educational services for the handicapped, so that their welfare, measured over a lifetime, is as close to the average as possible.

Veatch recognizes some of the counter-intuitive implications of his conclusions. He notes that other ethical principles (for example, autonomy) may have claims against justice in some circumstances. He is also worried by what his concept of justice may mean for the ethic of competition. Taking sport and higher education as examples, he suggests that the only real arguments in favour of rewards relate to the good that those with natural ability may bring to the community. Concentrating less on competition and more on co-operation could only be good for society.

The Foundations of Justice is both an excellent introduction to egalitarian notions of justice and a lucid application of justice theory to the problems of the handicapped. However, Veatch's arguments in favour of equality as the measure of a just society are unlikely to convince those who are not already sympathetic to his views. The 'faith moves' that lead Veatch to adopt an egalitarian stance can not, on his own admission, logically compel others to do the same. Even people who would usually stand in the same camp as Veatch may find his hardline support for equal outcomes offensive. Perhaps the great strength of The Foundations of Justice is that it does set out clearly where radical commitment of equality in health care may lead.

Whereas Veatch tackles ethical problems at a societal level, Shelp's Born to Die? is concerned far more with decision-making at the level of individuals. Shelp is writing about who should be responsible for decisions concerning seriously ill newborns and how far that responsibility should extend. It would be particularly helpful for anyone looking for an ethical perspective on the literature on parent-child relationships, legislative responses and developments in neonatal medicine. The ethics of neonatal intensive care is one of the classic topics of bioethics in both the United States and the United Kingdom (a point worth remarking on, given other divergences between the ethics industries of the two countries). It is also a topic about which the temptation is ever-present to collapse ethical dilemmas into technical rules. ${ }^{5}$ Shelp's main thesis stands on three premises. The first is that, historically and legally, children have been considered in relation to their parents: accordingly, parents bear the chief responsibility for the care and nurture of children. Secondly, the parental role should be seen as one of preparing the child for independence: at a minimum, parents should aim to foster in their children "a capability to relate, communicate, ambulate and perform tasks of basic hygiene, feeding, and dressing". Thirdly, the moral pluralism of our society legitimizes a broad range of parental responses to the dilemmas surrounding critically ill newborns.

The thesis itself is that parents are the proper decision-makers in situations concerning the imperilled neonate. Provided that their choices comply with those of any reasonable member of the moral community (and Shelp adopts a fairly loose definition of 'reasonable'), parents should be free to make any decision they think appropriate. The neonatologist's role is that of a "sustaining presence" who advises and co-operates with parents who are responsible for deciding the fate of their infant. Indeed, Shelp concludes, parents who choose active euthanasia for an infant "who will never attain a personal existence, never experience life as a net value, and/or never achieve a minimum level of independence" should be supported in their decision.

Shelp also suggests that human neonates are not 'persons' in the same sense as normal older humans (not 'persons in the strict sense', as Engelhardt would define them) and that the kill/let die distinction has no moral force. While it may be difficult to sustain a distinction between killing and letting die in borderline situations in neonatal intensive care, the more general distinction between commissions and omissions has been regarded as necessary by legal, moral and religious traditions. We would all recognize the difference in moral responsibility between throwing a baby into a raging torrent and patrolling river banks in case babies fell in. ${ }^{6}$ The whole topic of parental responsibility is much more complex than Shelp's treatment of it might indicate. For example, he does not address satisfactorily the question of how to deal with those parental choices which are not 'reasonable' whereas even Engelhardt, despite appearing to regard neonates as the property 
of parents, rather than as persons in the strict sense, would secure some rights to them in the light of consequences relevant to each case. Veatch takes a different approach again. He argues that parents should pursue the welfare of their children in single minded fashion, without regard for competing interests outside their family unit. He does not appear to recognize that a parent's notion of 'child's best interests' might not be the child's. It must be said, in addition, that Shelp's position offers little support to the medical and nursing personnel who are left to stand on the sidelines - supporting in practice a decision they may not support in conscience. $^{?}$

One older neonatologist of our acquaintance found Born to Die?'absorbing and illuminating. We suspect that at least some of his enthusiasm was due to the fact that Shelp was preaching to a convert. Readers are likely to find Shelp's arguments persuasive only if they are predisposed to accept them. In short, you will need to share his "faith moves" to be convinced.

Teachers of ethics to health care students become used to playing spot-the-ethical-issue in the neonatal intensive care unit and IVF clinic. Indeed, one feature of much of the voluminous American writing in bioethics is its concentration upon cases in extremis, in exotic settings. No doubt this is partly a reflection of the way in which medical work in America is organized but it does, also, fuel the misgiving that bioethics is a dance upon a stage of social arrangements and values that are not themselves subjected to ethical analysis. Just Health Care and Ethical Issues in Family Medicine are important books in this connection because each represents an effort to add ress the health-care system as well as the obvious dilemmas which arise within its units.

Norman Daniels has been gnawing away for several years at the ethical implications of the American health care system. ${ }^{*}$ That material is pulled together and reworked, to some extent, in Just Health Care: the first four chapters are an effort to spell out the philosophical implications of the title phrase; chapters five to eight apply the philosophy to questions of aged care, occupational health and the role of providers of health care; the last chapter is a brief enquiry into the usefulness for policy-makers of the kind of analysis presented in the preceding chapters. It must be said that the result is a collection of papers tending towards a theme, rather than a finished thesis.

In his introduction Daniels observes that the cost-containing environment in the United States is not alive with interest in philosophical questions about justice in the distribution of health care. Given the role-in-exile of the unspeakable ' $\mathrm{L}$-word' in the recent American election, he is probably right! Indeed, even to raise the topic is to invoke a flock of 'L-questions':

"To find . . . principles of justice for health care we must address questions such as these:

What kind of a social good is health care? What are its functions and do these make it different from other commodities?

Are there social obligations to provide health care?

What inequalities in its distribution are morally acceptable?

What limits do provider autonomy and individual liberties of physicians or patients place on the just distribtuion of health care?"

In an effort to answer those questions, Daniels asks another: is health care special? His answer has been the point of much of the criticism of his work" and wanders over two chapters of this book. Some people argue that health care needs are not special, provided that each person has a fair share of resources and income, "adequate to meet reasonable needs". Daniels holds that the scale used to measure needs should consider needs that are "objectively ascribable" and "objectively important". To construct the better scale, he sets off after the notion of "species-typical functioning", proceeding, by a rather circuitous argument, to define diseases as "deviations from the natural functional organization of a typical member of a species". He asserts that the line between disease and absence of disease is generally agreed and easy to draw - though more than a few historians of concepts of disease would doubt it. ${ }^{10} \mathrm{His}$ next step is a shift to the notion of "normal opportunity range": individual shares of the normal range of talents and skills will not be equal because disease detracts from the capacity of an individual to command that position on the normal range of opportunity which "his skills and talents would have made available to him were he healthy".

With health care, as with education, one is addressing "needs which are not equally distributed among individuals" but the unequal distribution of those needs has "great strategic importance for opportunity". At that point the Daniels L-faith statement appears: "from the perspective of justice, . . the moral function of the health care system must be to help guarantee fair equality of opportunity." That bald statement raises the question of equity of access to health care, about which there is little consensus because "access is itself a complicated notion. . [;] health care services are non-homogenous [and] have many functions" and questions about equitable access reflect more basic questions about distributive justice.

Daniels reviews a number of the accounts of what might be involved in equitable access to health 
care before concentrating, appropriately in the present climate of economism, on the role of the market as a distributor. The market approach amounts to saying that access to health care is equitable if there are "no information barriers, financial barriers or supply anomalies that prevent access to a reasonable or decent basic minimum of health care services." Even if the first three criteria were met, the difficulty would remain of deciding what is "a decent basic minimum". To define it relative to existing social practices "risks incorporating into the decent basic minimum all that is already askew in the health care system".

In any case, Daniels argues, these attempts to specify the "good" in health care miss the point that the system's capacity to enhance fair equality of opportunity is the best test of its justice. He adds that a system providing fair equality of opportunity is compatible with a multi-tiered health care system, "provides a principled way of characterising the health services that fall in the socially guaranteed tier" and "does not insist on equality of amenities that do not affect health status". Critics of the overtly two-tiered system which prevailed in Australia for many years (and threatens to return) - or observers of the 'creaming' and 'dumping' which DRG funding promotes in American hospitals - might be less sanguine."

If our account of the first half of Just Health Care seems laboured, we could plead the laborious style of the book, in mitigation - though that would constitute a second lapse of form. It would be fairer to Daniels to point out that he is a pioneer in the topics he has addressed: the number of American bioethicists with whom he could have debated his approach to public health and social justice is not large. ${ }^{12}$ The book is difficult but readers of this journal who have little appetite for philosophy should consider at least the chapter "Am I My Parents' Keeper" and the chapters on the powers of the American Occupational Health and Safety Administration and on the dilemma between risk and opportunity which is involved in efforts to enforce workplace safety. All three chapters raise ideas which could enrich the discussions of aged care and worker safety in Australia.

Christie and Hoffmaster's ethical perspective looks less like a faith statement than Engelhardt's, Veatch's or Daniels' but their work has some of the evangelical tone that seems to go with family medicine. Like Daniels', their work is remarkable because of their interest in a field of health care beyond the critical moment and the hospital setting. Like Daniels, again, they plough in a lonely paddock. ${ }^{13}$ We have found, in addition, that the large range of cases in their book can help to draw useful ethical reflections from medical students who have just returned from general practice placements.

The first section of Ethical Issues in Family Medicine deals with theoretical issues which arise from a role-description of family medicine not dissimilar to the description of general practice favoured by the Royal Australian College of General Practitioners. Family medicine/general practice involves providing continuing, comprehensive care for the whole person, taking on "problems of living", preventing ill-health and acting as the patient's advocate in dealings with the health system. Christie and Hoffmaster argue that such a role creates a moral expectation that physicians will assume broad responsibility for the welfare of their patients and will intervene in the psychological, behavioural, social and environmental dimensions of their patients' lives.

The assumption of 'broad responsibility', Christie and Hoffmaster suggest, could mean that it is appropriate for the doctor to withhold a diagnosis, if giving information would harm the patient. At this point, all good libertarians (and lots of other good people) will throw up their hands and yell 'What about autonomy?' Christie and Hoffmaster suggest that autonomy is an ambiguous and abstract concept, of little value in the real world. To grant autonomy primary status is to relegate the physician to a passive role. The conclusion of this section of the book is that any framework for medical ethics founded only on a theoretical approach to ethical dilemmas can be of little help to the family physician.

The second section of the book offers an alternative to the jaundiced view of 'top-down' approaches: it proposes a framework which begins with the scrutiny of cases and works up to principles. The authors explore the ethical problems which arise in family practice and use their definition of family medicine to offer guidelines for decision-making for example, there is a well-balanced study of the practical and philosophical dimensions of controlling patients' access to information, conflicts of values between patient and physician and intervening in patients' lifestyles. The result is an admirable attempt to place the experience of the general practitioner on the ethical agenda.

The attempt to provide a coherent theoretical framework is less successful. The 'bottom-up' approach is more 'top-down' than Christie and Hoffmaster care to admit; too often, the choice which they deem ethically appropriate is determined not by the peculiarities of the case but by the definition of family medicine which they have advocated. The chapter on autonomy is also particularly disappointing. Their argument that the principle of autonomy is open to a variety of mutually exclusive interpretations, and therefore useless in the real world, is simplistic. A more subtle 
analysis would have chosen from the definitions offered that which best suited the work of the family physician, and balanced it judiciously against the commitment to patient welfare.

We have described several of these books as faith statements: the title of our review suggests that we think it no bad thing if the description is valid. The choice of title, and our faith statement about bioethics, demand some comment. Bioethics is a boom topic in Australia, as it has been in America. Even in our little corner of the continent, the past four years have produced requests to teach or present papers on ethics to medical students, general nurses, physiotherapists, health surveyors, child welfare workers, paediatric nurses, medical administrators, political parties, hospital managers, radiotherapists, senior nursing staff, health and welfare chaplains, community nurses and medical educators and migrant nurses. Higher degree students keep bounding through the door. Earnest seekers after truth could easily have found themselves at an ethics conference a month. In loftier circles, bioethics centres have sprung up around the country. Statutory committees and public enquiries and parliamentary committees and Law Reform Commissions have all addressed bioethical questions. The Commonwealth government has set up National Bioethics Consultative Committee to advise on the ethical, legal and rocial isoues arising from selentlfle and medieal technology (partleularly reproductive teehnology), blomedieal and health related researeh, and the provilion and delivery of health services. The National Health and Medical Researeh Council has produced a report on ethles in researeh and tried to extend its protocols to other Commonwealth agencles, while institutional review boards have become eommon.

What does all this mean? Teaching ethici ean be a problem: Huty health=wervleas studentw, practically orlented, often find ease studies a rellef from roteleartiligi, down to eafth and not too diffieult: playing spot=the=dilemma ean be fun; andysing the ethical reasoning or eritielting the moral assumptions may draw less plaudits: Some of the comfrittees and boards have fulfilled the demoeratically neeesoafy, ethieally valid (in a secular; pluralist sodety) "enterpribe of eontroversy resolution"; others have been aeeused of providing the rhetoried sereen whieh will allow one group of athother to pursue its business as usual: Some of the aetivity has been designed to draw a mantle of lagal protedtion over the problentiatie eonsequenees of technological change in medicine and some has been no more than a "collapsing of ethical dilemmas into technical rules'.

Not enough of the teaching, conferring and enquiring, in our opinion, has extended to the analysis of the values which drive Australian society when it is doing health business. It is rare, outside Catholic circles, to hear contributions which make a faith statement and explore its implications. By comparison, the Veatch and Engelhardt books are valuable, but different, examples of how the texture of ethical discussion might be enriched in our setting. Do Australians still form a consensus around egalitarian justice? If not, either what refurbishing of that concept is necessary to make it acceptable or what alternative value can bind us - where 'us' is the population at large or the public health cadre? What values drive the Medical Research Ethics Committee of the NH\&MRC; how widely are they held; if they are not held widely, how is their particularity defended? What are the consequences, for the public health cadre or the medical profession or particular groups of 'the population at large', of a libertarian emphasis on individual autonomy?

Here, as in America, in our opinion, too much of the ethics effort has been at the technologically pointy end of the medical industry. By comparison, the Daniels and Christie and Hoffmaster books are valuable because they attend to topics like seneral practice and oecupational health and care of the aged which will affect people for most of their lives. What is the agenda of the national committees and public enquiries in Australia? Is the agenda yielded, by default, to IVF and intengive care? What would need to be done to ensure that the committees and enqulries engaged a broader spectrum of the population In a broadened agenda?

The conjunetion of falth and retson with bioethies is a reference to an anelent debate. 14 The key questlon in bloethies, as In ethles generally, is the Soeratie one, "how should one live?' That is a valulng, purposive question, about the Justifleation of life=aetlons. The most satisfaetory answer to the question is not the Soeratie or Kantian one, which defines morality by the rationality of agents, but the Aflototelian answer, whleh deseribes the harmonlous life of agents in themselvas and In relation to other agents; It takes strong assumptions - a faith - about the natufe of life to shape an athieal view about how it should be lived: It takes praetleal feasen to put the faith to work, in bioethies as in ethies generally: 
1. MacIntyre A. After Virtue: A study in moral theory. London: Duckworth, 1985 (1981).

2. Although it must be also said that he has probably stayed within the limits prescribed by Williams B. Ethics and the limits of philosophy. London: Fontana, 1985.

3. Compare Phillips DL. Toward a Just Social Order. New Jersey: Princeton University Press, 1986, chapter 5, for an extended discussion of moral socialization.

4. Veatch RM. A Theory of Medical Ethics. New York: Basic Books, 1981 is reviewed in Community Health Studies 1983; VII:201-209.

5. Veatch RM. The Technical Criteria Fallacy. Hastings Center Report 1977; 7:15-16; Reid R. Spina Bifida: The Fate of the Untreated. Hastings Center Report 1977; 7:16-19; Fost N. The Limited Moral Significance of Fetal Viability, Hastings Center Report 1980; 10:10-13; Arras JD. Toward an Ethic of Ambiguity. Hastings Center Report 1984, 14:25-33; and Kotch JB. Low Birthweight and Maternity Care for All. Journal of Publlc Health Polley 1986, 7:156-160.

6. Bok S. Death and Dying: Euthanasia and Sustaining Life, II Ethical Views in Reich WT. Encyclopedia of Bloethics. New York: The Free Press, 1978; 268-278.

7. The point is not dealt with very often but wee Skillman JJ. Ethical Dilemmus in the Care of the Critically III. Lancet 1974, 7881:634-637 and Younger SJ. et al. Resolving Problems at the Intensive Care Unit/Onsology Unit Interfuce. Perspect Blol Med 1988; 31: 299-308.

8. Danlels N, Rights to health eare and distributive Justlee: progrummatic worrles. Journal of Medicine and Phllosophy 1979; IV: 175-191; Danlels N. What is the obligutlon of the medieal profession in the distribution of health eare. Soctal Sctence and Medicine 1981; 15F: 129-133; Daniels N. Health Care Needs and Dlatrlbutive Justiee. Philosophy and Public Affairs 1981; 10: 146-179; Bayer, R., Caplan AL. and Danlels, N, In Search of Equlty. New York: The Hastings Center/Plenum Press, 1983; Danlels N. Justlee between Age Groups: Am I My Parents' Keeper? Healih and Society 1983; LXI: 489-522; and Daniels, N. Why saying no to patients in the United States is so hard: Cost containment, Justice and provider autonomy. $N$ EnglJ Med 1986; 314: 1380=3.

9. See, for example, Stern L. Opportunity and Health Cafa: Criticloms and Suggestions
Journal of Medicine and Philosophy 1983; VIII:339-362, and compare Churchill LR. Ethics and Economics in Search of a Common Language. Hastings Centre Report 1987; 41.

10. For example, several of the contributors to Wright P. \& Treacher A. eds. The Problem of Medical Knowledge. Examining the Social Construction of Medicine. Edinburgh University Press, 1982.

11. Mistichelli J. Diagnosis Related Groups (DRGs) and the prospective payment system: forecasting social implications Kennedy Institute of Ethics Scope note No. 4 is a useful summary; compare Veatch RM. DRGs and the Ethical Reallocation of Resources. Hastings Centre Report 1986; 16:32-40 and, for a medical perspective, Stern RS \& Epstein AM. Institutional responses to prospective payment based on diagnosis-related groups. $N$ Engl $J$ Med 1985; 312:621-627.

12. Our own, reasonably extenuive bibliography on 'justice and health care' revealed only the following handful of items directly relevant to Daniels' work: Beauchamp DE. Public Heulth as Socisl Justice Inquiry 1976; X11l:3-14; Branson R. Theories of Justice and Health Care. In:Reich, WT. ed. Encyclopedia of Bloethlcs Vol II. New York: The Free Press, 1978; 630. 637; Campbell AV. Medicine, Healih and Jusitce. The Problem of Priortiles. Edinburgh: Churchill Livingutone, 1978. Oreen RM. The Priority of Health Cure. Journal of Medirine and Philosophy 1983; 8:4 373-380; President's Commisulon for the Study of Ethieal Problems in Medicine and Blomedieal and Behavlourul Research. Securing Access to Healih Care: The Eithical Implications of Differences in the Avallabillty of Heallh Services. Washington D.C. 1983; and Bayer R, Caplan AL and Daniels N. In Search of Equity. New York: The Hastings Centre/Plenum Press, 1983.

13. Flannefy MA. Simple Living Hard Choices. Hastings Centre Report 1982;12:4;9-12; Sehrug B. Justice and the Justifiention of a Socid Polley: The Distribution of the Primary Cure Physielatis. Soctal Sclence and Medicine 1983. 17(15);1061=1074 1983; and Bryent JH. Prineiples of Justles as a Rasis for Conceptualizing a Health Care Syotem. Int d Health Serv 1979;7:4; 707-719.

14. We rely at this point on Williams op.cth., ehapters 14 